\title{
Anxiety, Depression and Health Profile in Mothers with Children in the Pediatric Intensive Care Unit
}

\section{Pediatrik Yoğun Bakım Ünitesindeki Annelerde Anksiyete, Depresyon ve Sağlık Profili}

\author{
(D) Burcu ÇABUK¹, iD Alis KOSTANOĞLU22
}

${ }^{1}$ Bezmialem Vakıf University Health Sciences Institute, Department of Physiotherapy and Rehabilitation, İstanbul, Turkey

${ }^{2}$ Bezmialem Vakıf University Faculty of Health Sciences, Department of Physiotherapy and Rehabilitation, İstanbul, Turkey

\begin{abstract}
Objective: The aim of this study was to investigate, anxiety, depression and health profile among mothers of patients at pediatric intensive care unit (PICU) and pediatric inpatient service (PIS).

Methods: The sample consisted of a total of 40 mothers, including mothers with children in a PICU (group I) and PIS (group II). The mothers' quality of life was measured with the Nottingham Health Profile (NHP), anxiety was measured with the State- Trait Anxiety Inventory (STAI), and depression levels were measured with the Beck Depression Inventory (Beck-D) for the all mothers.

Results: The mean age of the mothers was 31.5 years for group I and 31.25 years for group II. The mean total NHP score of the mothers was 279.0 for group I and 113.33 for group II. The mean total STAI-S score of mothers was 37.1 for group I and 36.65 for group II. The mean total of STAI-T score of mothers was 46.9 for group I and 47.75 for group II. The mean total Beck-D score was 39.7 for group I and 18.5 for group II. There was a statistically significant differences in the levels of anxiety, depression and health profile between the mothers with children in the PICU and those with children in the PIS $(\mathrm{p}<0.001)$.
\end{abstract}

Conclusion: This study showed that having a critically ill child at a PICU unit has negative 17 effect on mothers' depression levels, state anxiety levels and health profile.

Keywords: Critical illness, health profile, intensive care, parents, stress

\section{ÖZ}

Amaç: Bu çalışmanın amacı, pediatrik yoğun bakım ünitesinde (PYBÜ) ve pediyatrik yatılı servisteki (PYS) hastaların anneleri arasında anksiyete, depresyon ve sağlık profilini araştırmaktır.

Yöntemler: Örneklem, PYBÜ (grup I) ve PYS'de (grup II) çocuğu olan anneler dahil olmak üzere toplam 40 anneden oluşmuştur. Annelerin yaşam kalitesi Nottingham Sağlık Profili (NHP) ile, anksiyete Durum-Sürekli Kaygı Envanteri (STAI) ile, depresyon düzeyleri ise tüm anneler için Beck Depresyon Envanteri (Beck-D) ile ölçülmüştür.

Bulgular: Annelerin yaş ortalaması grup I için 31,5, grup II için 31,25 idi. Annelerinortalama toplam NHP skoru grup I için 279,0, grup II için 113,33 idi. Annelerin ortalama

toplam STAI-S skoru grup I için 37,1 ve grup II için 36,65 idi. Ortalama STAI-T puanortalaması, grup I için 46,9, grup II için 47,75 idi. Ortalama Beck-D skoru grup I için 39,7, grup II için 18,5 idi. PICU'lu çocukları olan anneler ile PIS'li çocukları olan anksiyete, depresyon ve sağlık profili düzeyleri arasında istatistiksel olarak anlamlı bir fark vardı $(\mathrm{p}<0,001)$.

Sonuç: Bu çalışma, PYBÜ'de kritik hasta bir çocuğa sahip olmanın annelerin depresyon düzeyleri, durumluk kaygı düzeyleri ve sağlık profili üzerinde olumsuz etkisi olduğunu göstermiştir.

Anahtar Sözcükler: Kritik hastalık, sağlık profili, yoğun bakım, ebeveyn, stres
Address for Correspondence: Alis KOSTANOǦLU, Bezmialem Vakıf University Faculty of Health Sciences, Department of Physiotherapy and Rehabilitation, İstanbul, Turkey

E-mail: aliskostanoglu@yahoo.com ORCID ID: orcid.org/0000-0002-6912-9836
Received: 11.06 .2019

Accepted: 07.01.2020

Cite this article as: Çabuk B, Kostanoğlu A. Anxiety, Depression and Health Profile in Mothers with Children in the Pediatric Intensive Care Unit. Bezmialem Science 2020;8(2):150-5. 


\section{Introduction}

Acceptance of the child to the pediatric intensive care unit (PICU) is among one of the most stressful parenting experiences. Families of children with chronic or severe illnesses sometimes face difficulties that have never been considered before. The result for the child is unknown, procedures and treatments may be invasive and uncomfortable for the patient, and the environment may include tensions that may affect the level of stress of the parents (1).Intensive care units are a complex and stressful environment for patients. It may also haveimportant physical, cognitive, psychological and functional consequences for patient relatives. Various treatment and care methods are applied by multidisciplinary staff for the patients that have an acute-chronic disease or disease predicted to develop (2). Hospitalization of a family member in critical care units causes overwhelming stress and distress (3).

PICU support children who are admitted with life-threatening medical conditions, as well as being intended for treating children with traumatic, surgical, internal, acute and chronic pediatric diseases with mostly complex approaches. Innovations in pediatric surgery, hematology/oncology and state-of-theart advanced life support techniques have expandedtreatment options for critically ill infants and children. Mortality rates in childhood critical illness and injury have plummeted, and death rates in PICUs are uniformly low even fortertiary units at $1.5 \%$ to $8 \%$ (4). Additionally, since the technological environment, equipment and operation at the PICU are different from the other departments of hospitals, being treated at the PICU is a very troubling and stressful experience for both patients and their parents (5). Dramatic oscillations in the orbit of the disease may vary both to deterioration and recovery. This is a source of distress not only for the child in PICU but for the whole family (6).

A disease of the child causes important changes in the life of a family. Accordingly, everything will become different in comparison to before the child's disease, the life of the family will change completely, material costs will increase, and spiritual losses will be experienced. The sick child, the parents, siblings, even close relatives will be affected negatively because of stress created by illness and treatment.

Mothers get under stress for their children due to the uncertain results of short- or long-term conditions and possibilities like disability and death. Having a sick child increases the anxietyof mothers whether children are at the PICU or the inpatient hospital service.

Moreover, desperation of not being able to intervene in case of need increases anxiety and stress (7). Images that come from monitors, alarms of machines and different types of equipment, thesound of the staff, bright lights, smells, insomnia, witnessing the invasive interventions ontheir own children or other children constitute sources of stress for people who fall under the responsibility of looking after patients (8). It is shown in studies that lack of daylight, usingtechnologically complex machines, visiting at fixed times or being completely forbidden fromvisiting at certain hours cause stress and anxiety for patients and their families at these units (9). Depression is among the many psychological disorders that occur in all societies, and it may depend on many reasons. It is clear that a child's health status will affect the psychological well-being and quality of life of the family. Family members want to support,comfort, get close to and have the feeling of touching the patient as in normal times. Similarly, the patients that are at ICU need to be supported by their family members (10).

The purpose of our study was to evaluate the anxiety, depression and health profile among mothers at PICUs and PIS.

\section{Methods}

\section{Study Design and Setting}

This cross-sectional, single-center study was conducted with mothers of children who were hospitalized at Children's Health and Diseases Departments.

\section{Subjects}

The sample consisted of 40 children and their mothers. The children were recruited consecutively from amongst the patients who were hospitalized at the pediatric intensive care unit or the pediatric inpatient service at first time within the 6-month period from July 2016 to October 2016.

The inclusion criteria for mothers were as follows: hospitalized a child at PICU or PIS (Children's Health and Diseases Department); staying in PICU and PIS minimum 24 hours-3 months at first time; smaller than 12 years old for the children; absence of a severe or chronic medical condition (i.e., diabetes mellitus, musculoskeletal disorders); absence of a patient or a disabled person for whom the mother is responsible; absence of an application to an patient and/or outpatient clinic for kind of medical support within the last 3-months period prior to the study, being an adult and volunteering to participate in the study. Mothers of children who had cognitive or mental impairment as reported in their medical history and chronic psychobiological disorders were excluded. Group I $(\mathrm{n}=20)$ was defined as the mothers of children at the PICU, and the mothers of children at the pediatric inpatient service was in group II $(n=20)$. The characteristics of the mothers and their children are listed in Table 1.

Approval of the local Ethics Committee was obtained for this study. Clinical Research Ethics committee decision no:1/1524.06.2016. Written informed consent was obtained from each participant. The study was conducted in accordance with the principles of the Declaration of Helsinki.

\section{Data Collection}

Data including age, sex, gestation week, birth type, birth weight, height and weight, diagnosis and time of diagnosis, frequency of hospitalization, cost of treatment, accompanying diseases, presence of intubation, surgeries, medication and doses, analgesics use, time of hospitalization, nutrition type of the 
children were collected and recorded in the Child Clinical Data Form. Data including age, number of live and dead births, the age of becoming a mother for the first time, duration of education, working situation, previous psychiatric treatments and previous traumatic events, presence of disease of the mothers, financial situation of the families, the parents' expectation for the future of the child and daily hours of care were also collected and recorded in the Parent Clinical Data Form.

The risk of depression and depressive symptoms were assessed in the subject using the BeckDepression Inventory (Beck-D). It is a very reliable and well-validated scale that is easy to apply $(11,12)$. This self-assessment scale that was developed by Beck as a 4-point Likert-type to measure pessimism, sense of failure, lack of satisfaction, feelings of guilt, restlessness, depressive symptoms such as fatigue, appetite, indecision, sleep disturbance, social withdrawal is made of 21 items. Each item has a 4-point scale self-assessment scoring whichidentifies depressive symptoms. The total score is between 0 points and 63 points.

The State-Trait Anxiety Inventory (STAI) is a 40-item inventory that is used to measurelevels of state and trait anxiety $(13,14)$. The questionnaire has two parts: the SATI-S (20 questions) score, which provides the level of state anxiety at the time of completing theinventory, and the STAI-T (20 questions) score, which measures the inherent trait anxiety level of the subjects. There are four options for each expression in the STAI. These are; Not at all (1), Somewhat (2), Moderately so (3) and Very much so (4). In the inventory, the items $1,2,5,8,10,11,15,16,19$

Table 1. Participant characteristics $(n=40)$ participants 373

Group I ( $n=20)$

Mean \pm SD or n (\%) Group II ( $n=20)$

\begin{tabular}{|c|c|c|}
\hline \multicolumn{3}{|c|}{ Maternal characteristics } \\
\hline Age at delivery (years) & $31.5 \pm 3.76$ & $31.25 \pm 4.86$ \\
\hline \multicolumn{3}{|l|}{ Educational level } \\
\hline Primary school & $5(25)$ & $14(70)$ \\
\hline High school & $14(70)$ & $4(20)$ \\
\hline University & $1(5)$ & $2(10)$ \\
\hline Employed & $5(25)$ & $2(10)$ \\
\hline Housewife & $15(75)$ & $18(90)$ \\
\hline \multicolumn{3}{|l|}{ Infant characteristics } \\
\hline \multicolumn{3}{|l|}{ Gender } \\
\hline Boys & $8(40)$ & $10(50)$ \\
\hline Girls & $12(60)$ & $10(50)$ \\
\hline Birthweight (g) & $3002.7 \pm 405.3$ & $3113.67 \pm 259.1$ \\
\hline \multicolumn{3}{|l|}{ Diagnosis } \\
\hline Neurologic disorders & $5(25)$ & $5(25)$ \\
\hline Surgery & $6(30)$ & $5(25)$ \\
\hline Respiratory failure & $9(45)$ & $10(50)$ \\
\hline
\end{tabular}

and 20 are the items that are inversely scored. In the assessment, the state anxiety point is calculated by extracting the result from the total point of direct assessments to opposite expressions and adding 50 points. There are responses as Never (1), Seldom (2), Often (3), Always (4) in the Trait Anxiety Scale. In this section, the inverselyscored expressions are the 21, 26, 27, 30, 33, 36 and $39^{\text {th }}$ items. The trait anxiety point is calculated extracting the result from total point of direct assessments and adding 35 points. Both levels of anxiety are intended to be determined because state anxiety level rises in people who have a high level of anxiety. In general, if the scores of state and trait anxiety levels are high, the general anxiety level is high, and a person who has 60 points or more, they should receive professional help.

The Nottingham Health Profile (NHP) that was developed by Hunt and McEwen is used to determine the relationship between health problems and common daily activities (15). The validity and reliability of the Turkish version of NHP have been well established through scientific adaptation procedures (16). This survey includes 38 items and assesses 6 dimensions about life status like energy ( 3 items), pain ( 8 items), emotional reactions (9 items), sleep (5 items), social isolation (5 items) and physical activities ( 8 items). The questions are answered by Yes/ No statements. Each section is scored between 0 and 100 . Ascore of 0 is the best possible health status, and a score of 100 is the worst possible health status. In this study, the sub-scores and total scores of NHP were assessed. The total score was obtained by combining the sub-scores of NHP.

Questionnaires, which took approximately 30 minutes to complete, were given to the participants by the same researcher, in a private room at the hospital in face-to-faceinterviews.

\section{Statistical Analysis}

Statistical analysis was carried out by using the SPSS software (version 21; the Statistical Package for the Social Sciences, Chicago, IL, USA). Descriptive characteristics are presented as mean \pm standard deviation or $\mathrm{n}(\%)$. Student's $\mathrm{t}$-test and KruskalWallis test were used to test thedifferences in the BECK-D, STAI and NHP scores between the two groups. The anxiety, depression and health profile measurements of the mothers of children in different disease groups were compared with one-way analysis of variance (ANOVA) in independent groups. The level of statistical significance was accepted as $\mathrm{p}<0.05$.

\section{Results}

The mean age of mothers in the sample $(\mathrm{n}=40)$ was $31.37 \pm 4.31$ years. The proportions ofprimary school, high school and university graduates were $47.5 \%, 45 \%$ and $7.5 \%$, respectively. The mean age of the mothers in group I $(n=20)$ was $31.5 \pm 3.76$ years (Table 1). Among the mothers in this group, $25 \%$ were employed, and $75 \%$ were housewives. Theproportions of primary school, high school and university graduates were $25 \%, 70 \%$ and $5 \%$, respectively. The mean age of the mothers in group II $(\mathrm{n}=20)$ was $31.25 \pm 4.86$ years. Among mothers in this group, $10 \%$ were employed, and $90 \%$ were housewives. The proportions of primary school, high school and university 
graduates were $70 \%, 20 \%$ and $10 \%$, respectively. There was a significant difference in the educational statuses between the groups $(p=0.01)$, but there was no significant difference between the groups regarding the mothers' age $(p=0.84)$ or occupational status $(p=0.21)$. There was no statistically significant difference in the demographic characteristics of the mothers in the two groups ( $\mathrm{p}>0.05)$. The children at the PICU were diagnosed with $5(25 \%)$ neurological diseases, $6(30 \%)$ postoperative surgeries and $9(45 \%)$ respiratory failures, and they all received mechanical ventilator support. Children who were hospitalized included 5 (25\%) with neurological diseases, $5(25 \%)$ with postoperative surgery and $10(50 \%)$ with respiratory failure. 1

Among the Beck-D Total Scores the mothers in group I, the minimum score was 18 , the maximum score was 56 , and the mean score was $39.7 \pm 9.71$. The minimum score in the mothers of group II was 5, maximum score was 31 and the mean was $18.5 \pm 7.94$ (Table 2). There was a statistically significant difference between the groups $(\mathrm{p}<0.001)$.

The mothers' state/trait anxiety scores are shown in Table 2. The mothers in Group I had significantly higher STAI-S scores than those in group II (36.5 v 31.3; $\mathrm{p}=0.001)$. Their mean STAI-T scores were 47.75 and 46.9 , respectively. There were no significant differences between the groups in terms of their STAI-T anxiety scores $(\mathrm{p}=0.461)$.

Table 2. The Mean Values For Beck Depression Inventory and STAI Form Scores in Group I 398 and Group II ( $n=40$ participants)

\begin{tabular}{|l|l|l|l|} 
& Group I $(n=20)$ & Group II $(n=20)$ & $p$ \\
\hline BECK-D & Mean \pm SD & Mean \pm SD & \\
STAI-S & $39.7 \pm 9.71$ & $18.5 \pm 7.94$ & 0.001 \\
STAI-T & $36.5 \pm 3.48$ & $31.3 \pm 4.6$ & 0.001 \\
\hline
\end{tabular}

BECK-D: Beck Depression Inventory Total score, STAI-S: The Anxiety InventoryState, STAI-T: The State-Trait Anxiety Inventory-Trait, SD: Standard deviation

Table 3. The Mean Values For Nottingham Health Profile Subscale Scores in Group I and 415 Group II

\begin{tabular}{|c|c|c|c|}
\hline & Group I $(n=20)$ & Group II $(n=20)$ & $\mathrm{p}$ \\
\hline & Mean \pm SD & Mean \pm SD & \\
\hline \multicolumn{4}{|c|}{ Nottingham health profile } \\
\hline Nel & $74.12 \pm 29.8$ & $27.5 \pm 34.88$ & 0.001 \\
\hline $\mathrm{Np}$ & $21.65 \pm 24.9$ & $9.99 \pm 22.5$ & 0.30 \\
\hline $\mathrm{Ner}$ & $75.2 \pm 23.8$ & $36.16 \pm 28.39$ & 0.001 \\
\hline Ns & $34.7 \pm 26.9$ & $15.6 \pm 22.9$ & 0.008 \\
\hline Nsi & $58.5 \pm 24.9$ & $19.14 \pm 21.9$ & 0.001 \\
\hline Npa & $14.7 \pm 15.8$ & $4.8 \pm 9.12$ & 0.076 \\
\hline Nottingham total & $279.0 \pm 83.1$ & $113.33 \pm 76.97$ & 0.001 \\
\hline
\end{tabular}

Nel: Energy level, Np: Pain, Ner: Emotional reaction, Ns: Sleep, Nsi: Social isolation, Npa: Physical activity, SD: Standard deviation
The NHP scores of mothers are shown in Table 3. There were highly significant differences in the energy level, emotional reactions, sleep, social isolation and total scores of NHP between the groups $(\mathrm{p}<0.001)$. Group I had worse health profile. PICU group of children were divided into three subgroups as neurological $(n=5)$, surgical $(n=6)$ and respiratory failure $(n=9)$ patients. When the anxiety, depression and quality of life levels of the mothers of children in different disease groups were compared, there was no statistically significant differenceamong the disease groups in terms of anxiety, depression or health profile levels $(p>0.05)$.The children at the PIS were divided into three subgroups as neurological $(n=5)$, surgical $(n=5)$ and respiratory failure $(n=10)$ groups for reasons of hospitalization. When the anxiety, depression and health profile measurements of the mothers of children in different disease groups were compared in independent groups, no statistically significant difference was found among the disease groups in terms of anxiety, depression or health profile $(\mathrm{p}>0.05)$.

\section{Discussion}

The results of this study showed that having a critically ill child at PICU has negative effect on mothers' depression levels, state anxiety levels and health profile status.

In particular, parents at PICU experience traumatic and negative emotions in a wide range. This is because they usually must make complex decisions about the critical illness of their children. These decisions could include some big and important operations and surgical procedures like brain operations, tracheostomy and gastrostomy intubation. Although these invasive operations are life-saving for children, they may cause depression, anxiety, social isolation and anger in their lives (3). Parents experience the stress of having a sick or injured child at the PICU, and they must be provided with continuous information so that they can absorb and process information (17). Carlson et al. (18) stated that frequent visits of the family members to the intensive care unit could provide more information about the medical condition of the patient, the families are more comfortable in dealing with the stress of their situation, and the communication with the medical team is easier. In this study, the primary caregivers were mothers, and although the anxiety and depression levels of the mothers were affected, the fact that they accompanied their children for 16 hours to participate in the nursing process and that medical information was accessed more frequently increased the adaptation of the mothers to the process. It facilitated their acceptance of the disease. Thus, they might need support and encouragement.

In addition to the severity of the status and disease variables, parental anxiety increased, and quality of life was reduced. A worried parent is more likely to perceive a higher risk for his child and misinterpret information about his child's condition. In a study with parents of children admitted to PICU, parents had a high level of anxiety within the first 24 hours (19). The authors hypothesized that higher parental anxiety would affect medical information 2adversely. The initial concern after being admitted to the PICU is usually reduced over time, which makes 
it easier for parents to be informed (20). Mothers' anxiety levels, family dynamics and hospitalizations of the child may be affected by factors other than children's

illnesses. In our study, the reason that the mothers had more trait anxiety scores at the PICU than those who were at the PIS may be the anxiety that their children may change momentarily at the intensive care unit.

In our study, the reason why mothers at the PICU had higher state anxiety scores than thechildren at the PIS might be that the mothers of these children were concerned that their children's condition may change fast at the intensive care unit. Actually, the mothers were staying with their children for about 16 hours. Medical staff provided information continuously. We believe that this anxiety depends on the condition of the child and their dependence on the mechanical ventilator.

Parents may need to apply for support by others like physicians, other children's healthcareteams or other family members. Emotional overload and reactions could be reasons for this guidance. Parents who are worried about their children have to be informed in an appropriate and clear manner, to provide them with support and specific advice (21). Similarly, in ourstudy, the Nsi (social isolation) NHP score was higher than in Group I than Group II.Moreover, Group I had significantly higher scores of NSP than those in Group II (emotional reactions). We believe that this is due to the fact that these children's situation is more critical like the environment they are in.

Studies on children at PICUs usually focused on diseases and patient care, and the parent side has been relatively neglected. Our literature review revealed a limited number of studies that examined the quality of life mothers of children at PICUs.

According to the report published by WHO in 2004 on prevention of mental problems, stressful life events, physical discomfort and disruption of family order affect mental health risk factors. If these conditions persist for a long time, problems such as risk of cardiovascular disease and cancer increase (22). In our study, we believe that Group I had higher NHP Nel (energy) and $\mathrm{Np}$ (pain) scores than Group II, and these mothers felt more tired, which may cause some physical disturbances in the longrun. Although the $\mathrm{N}(\mathrm{p})$ scores were high in bothgroups, there was no significant difference between the groups. We believe that the physical conditions and care load of the mothers should be reviewed. Accompanying times may beshared with other family members. Recommendations may be made to attendants aboutprotection of their posture and musculoskeletal systems while putting the child on their lap, breastfeeding and sitting.

There are many studies in the literature that measured the quality of life of parents in negative situations. In 2010, Yilmaz et al. (23) carried out a study with 40 children with diagnoses of neuromuscular diseases. The health related quality of life levels of the mothers were assessed with the Turkish version of the NHP and Beck-D, while the Wee-Functional Independence Measure (Wee-FIM) was used to determine of functional independence levels of the children. They found that the functional levels of children affect the quality life of mothers. There was a moderate correlation between the total NHP scores of the mothers and the total FIM score and sphincter control of the child, while it was weakly correlated with the locomotion of the child $(\mathrm{p}<0.001)$. In any case of illness of children, including neuromuscular diseases, cancer and cerebral palsy, the illness was found to negatively impact maternal health related quality of life. In 2015, Erdogan et al. (24) applied Beck-D to the parents of 25 children in at a PICU to assess the depression levels of parents, compare these levels based on whether there is a difference between mothers and fathers. The depression rates were significantly higher in both the mother and father of the children at the PICU than those in the normal population. The study revealed the necessity of providing psychological counseling and psychiatric support to the parents of children. Adanir et al. (25) investigated the psychopathology in pediatric BMT (bone marrow transplantation) survivors and their mothers in comparison to healthy controls in 2017. The researchers used the Symptom Checklist-90-Revised (SCL90-R) tool to assess psychopathology in mothers. Accordingly, clinicians should be aware of psychiatric symptoms or disease of the mothers whose children were operated or have experienced life- threatening conditions. Moreover, psychosocial support with medical treatment is very important.

Limitations of this study include its small sample size and assessment of only mothers. Additionally, the single-center methodology is another limitation of this study. Despite limitations, these findings suggest that mothers who have a child at PICU may have more stress, anxiety, depression, and so, low health profile.

\section{Conclusion}

The PICU should include managing not only a sick or injured child, but also the problems of the rest of the family members. In addition to the technical aspects of care, emotional support is also needed. Future research should not only focus on critically ill children at PICUs but also psychological support for their mothers. Healthcare professionals should consider and be aware of the psychological status and the health profile of the mothers.

\section{Ethics}

Ethics Committee Approval: Approval of the local Ethics Committee was obtained for this study. Clinical Research Ethics committee decision no:1/15-24.06.2016.

Informed Consent: Written informed consent was obtained from each participant.

Peer-review: Internally peer reviewed.

\section{Authorship Contributions}

Concept: B.Ç., A.K., Design: B.Ç., A.K., Data Collection or Processing: B.Ç., A.K., Analysis or Interpretation: B.Ç., A.K., Literature Search: B.Ç., A.K., Writing: B.Ç., A.K.

Conflict of Interest: No conflict of interest was declared by the authors. 
Financial Disclosure: The authors declared that this study received no financial support.

\section{References}

1. Lisanti AJ, Allen LR, Kelly L, Medoff-Cooper B. Maternal stress and anxiety in the pediatric cardiac intensive care unit. Am J Crit Care 2017;26:118-25.

2. Azoulay E, Pochard F, Kentish-Barnes N, Chevret S, Aboab J, Adrie C, et al. FAMIREA Study Group: Risk of post-traumatic stress symptoms in family members of intensive care unit patients. Am J Respir Crit Care Med 2005;171:987-94.

3. Pochard F, Azoulay E, Chevret S, Lemaire F, Hubert P, Canoui P, et al. Symptoms of anxiety and depression in family members of intensive care unit patients: ethical hypothesis regarding decision-making capacity. Crit Care Med 2001;29:1893-7.

4. Nicholson CE. Pediatric critical care for children with congenital neurodevelopmental 316 diagnoses. Pediatr Crit Care Med 2004;5:407-8.

5. Williams CM. The identification of family members' contribution to patients' care in the intensive care unit: a naturalistic inquiry. Nurs Crit Care 2005;10:6-14.

6. Fuhrman BP, Zimmerman J, eds. Pediatric Critical Care. 3rd ed. Philadelphia, PA: Mosby Elsevier; 2006;35-40.

7. Govier L. Spiritual Care In Nursing: A Systematic Approach. Nurs Stand 2000;14:32-6.

8. Rennick JE, Dougherty G, Chambers C, Stremler R, Childerhose JE, Stack DM, et al. Children's psychological and behavioral responses following pediatric intensive care unit hospitalization: the caring intensively study. BMC Pediatrics 2014;14:276.

9. Colville G, Darkins J, Hesketh J, Bennett V, Alcock J, Noyes J. The impact on parents of a child's admission to intensive care: integration of qualitative findings from a cross-sectional study. Intensive Crit Care Nurs 2009;25:72-9.

10. Ratliffe CE, Harrigan RC, Haley J, Tse A, Olson T. Stress in families with medically fragile children. Issues Compr. Pediatr Nurs 2002;25:167-88.

11. Beck AT, Ward CH, Mendelson M, Mock J, Erbaugh J. An inventory for measuring depression. Arch Gen Psychiatry 1961; 4: 561-71.

12. Hisli N. Beck A study on the validity of Beck Depression Inventory. Psikoloji Dergisi 1988;6:118-22.

13. Spielberger CD, Sydeman SJ, Owen AE, Marsh BJ. Measuring anxiety and anger with the State-Trait Anxiety Inventory (STAI) and the
State-Trait Anger Expression Inventory (STAXI). In M. E. Maruish (eds.), The use of psychological testing for treatment planning and outcomes assessment 1999;p.993-1021.

14. Öner N, LeCompte WA. Durumluk Sürekli Kaygı Envanteri El Kitabı. İstanbul Boğaziçi Üniversitesi Yayınları 1985;333.

15. Hunt SM, McKenna SP, McEwen J, Williams J, Papp E. The Nottingham Health Profile: subjective health status and medical consultations. Soc. Sci. \& Med. Vol. Part A: Medical Psychology \& Medical Sociology 1981;15:221-9.

16. Küçükdeveci AA, McKenna SP, Kutlay S, Gürsel Y, Whalley D, Arasil T. The development and psychometric assessment of the Turkish version of the Nottingham Health Profile. Int J Rehabil Res 2000;23:31-8.

17. Sweet $\mathrm{L}, \mathrm{Mannix}$ T. Identification of parental stressors in an Australian neonatal 348 intensive care unit. Neonatal Pediat Chil 2012;15:8-16.

18. Carlson EB, Spain D, Muhtadie L, McDade-Montez L, Macia KS. Care and Caring in the ICU: Family Members' Distress and Perceptions about Staff Skills, Communication, and Emotional Support. J Crit Care 2015;3:557- 61.

19. Needle JS, O'riordan M, Smith PG. Parental anxiety and medical comprehension within 24 hrs of a child's admission to the pediatric intensive care unit. Pediatr Crit Care Med 2009;10:668-74.

20. Huckabay LM, Tilem-Kessler D. Patterns of parental stress in PICU emergency admission. Dimens Crit Care Nurs 1999;18:36.

21. Madrigal VN, Carroll KW, Faerber JA, Walter JK, Morrison WE, Feudtner C. Parental sources of support and guidance when making difficult decisions in the pediatric intensive care unit. J Pediatr 2016;169:221-6.

22. Group TW. The World Health Organization Quality of Life assessment (WHOQOL): Development and general psychometric properties. Soc Sci Med 1998;46:1569-85.

23. Yılmaz O, Yıldırım SA, Öksüz C, Atay S, Turan E. Mothers' depression and health related quality of life in neuromuscular diseases: Role of functional independence level of the children. Pediatr Int 2010;52:648-52.

24. Erdoğan S, Oto A, Boşnak M. Depression Status in Children's Parents During Hospitalization in the in the Pediatric Intensive Care Unit. ACU Sağlık Bil Derg 2016; 367 2:79-82.

25. Sürer Adanir A, Taşkiran G, Küpesiz OA, Özatalay E. Psychopathology in pediatric bone marrow transplantation survivors and their mothers. Pediatr Int 2017;979-85. 